\title{
Politieke transformatisme in Suid-Afrika: Impli- kasies vir die staat, die ekonomie en die samelewing Political transformationism in South Africa: Implications for the state, the economy and society
}

\author{
André Duvenhage \\ Politieke wetenskap \\ Noordwes-Universiteit \\ Potchefstroom \\ Suid-Afrika \\ E-pos: Andre.Duvenhage@nwu.ac.za
}

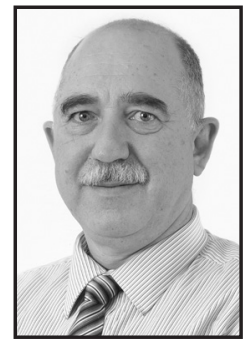

André Duvenhage

AndRÉ Duvenhage, 'n navorsingsprofessor verbonde aan die Noordwes-Universiteit, is 'n politieke wetenskaplike, en spesialiseer in die veld van politieke verandering soos van toepassing in die Suid-Afrikaanse konteks. Hy is 'n bekende in media- en joernalistieke kringe en word dikwels as politieke kommentator geraadpleeg. Hy is reeds meer as 35 jaar verbonde aan akademiese instellings soos die Universiteit van die Vrystaat en die Noordwes-Universiteit. Sy groot belangstelling is toekomsstudies en hy werk ook in die veld van scenario-ontledings.
ANDRÉ DuVenhage, a research professor at the North West Uiversity in Potchefstroom, is a political scientist, specialising in the field of political change as applied to the South African context. He is well-known in media and journalistic circles, and is often heard as political commentator. He has been an academic at institutions such as the University of the Free State (Bloemfontein) and North West University (Potchefstroom) for more than 35 years. His major interest is future studies and he also works in the field of scenario analysis.

\section{ABSTRACT \\ Political transformationism in South Africa: Implications for the state, the economy and society}

Forms of political and social engineering, for example colonisation, apartheid and forms of radical socialism (Ujamaa - socialism in Tanzania, and radical land reform in Zimbabwe), proved to be mostly failures with catastrophic implications for the various states, their economies and even the societies involved. Often the opposite of what exactly had been envisaged, was achieved. In this regard, the failure of apartheid (sometimes described as separate development) is still freshly remembered as a pertinent example of the abovementioned instances of political and social engineering.

Proceeding from the idea (or ideology) of the National Democratic Revolution (NDR), the overarching policy framework of political transformation has since been established in

\begin{tabular}{|c|c|c|}
\hline $\begin{array}{l}\text { Datums: } \\
\text { Ontvang: 2021-06-30 }\end{array}$ & Goedgekeur: 2021-07-20 & Gepubliseer: September 2021 \\
\hline
\end{tabular}


South Africa - the response to the former apartheid and colonial practices preceding the country's change to a democratically elected government in 1994. The objective of the ideology informing NDR policies is the establishment of a society that strives to become reconciling, non-sexist and aimed at development in a radical transformative way. The central focus is representativity at all levels of society, including the state, the economy and civil society.

This research states as hypothesis that political transformation (transformationism) the ideology currently prevalent in South Africa, is doomed to failure and that this failure is not only already observable, but holds far reaching implications for the state, the economy and greater society in future.

My aim is to undertake a thorough investigation and critical analysis of political transformation as the overarching political ideology in South Africa. Such evaluation is undertaken in terms of the rule of law adage ("Rechtsstaat" notion) as norm, as well as connected democratic criteria according to which political, economic and social freedom are taken as normative basis and point of departure.

KEYWORDS: $\quad$ Political transformation; transformationism; social and political engineering; "regstaat" (constitutional state); ANC; ideology; National Democratic Revolution; state capture; corruption

TREFWOORDE: Politieke transformasie; transformatisme; sosiogeniëring; regstaat; ANC; ideologie; Nasionaal Demokratiese Rewolusie; staatskaping; korrupsie

\section{OPSOMMING}

Vorme van sosiogeniëring, byvoorbeeld kolonisasie, apartheid en vorme van radikale sosialisme (Ujamaa - sosialisme in Tanzanië, en radikale grondhervorming in Zimbabwe), was meestal 'n mislukking met katastrofiese gevolge vir die onderskeie state, hul ekonomieë en selfs die betrokke samelewingsordes. Dikwels is die omgekeerde bereik van juis dít wat in die vooruitsig gestel is. Die mislukking van apartheid (soms voorgehou as afsonderlike ontwikkeling) is nog vars in die geheue as voorbeeld van bogenoemde.

Uitgaande van die idee (of ideologie) van die Nasionaal Demokratiese Rewolusie, het die oorhoofse beleidsraamwerk van politieke transformasie in Suid Afrika beslag gekry - die teenvoeter vir die historiese apartheid- en koloniale praktyke. Die doel van hierdie ideologie is om, met behulp van radikale (transformatiewe verandering), 'n samelewing wat verenigend, nierassig, nieseksisties en ontwikkelingsgerig is te bewerkstellig. Die sentrale fokus is verteenwoordigendheid op alle vlakke van die samelewing met inbegrip van die staat, die ekonomie en die burgerlike samelewing.

Hierdie navorsing stel as hipotese dat politieke transformasie, die ideologie wat in SuidAfrika toegepas word, tot mislukking gedoem is en dat hierdie mislukking nie net reeds waarneembaar is nie, maar verreikende toekomstige implikasies inhou vir die staat, die ekonomie en die groter samelewing.

Die doel van hierdie artikel is dus 'n grondige ondersoek na en kritiese ontleding van transformatisme as die heersende politieke ideologie in Suid-Afrika. Hierdie beoordeling geskied teen die agtergrond van die regstaatidee as norm, asook verbandhoudende demokratiese kriteria waarin politieke, ekonomiese en sosiale vryheid as normatiewe grondslag en vertrekpunt geneem word. 


\section{INLEIDING}

Die beëindiging van die apartheidsbedeling en verbandhoudende sake soos rasgebaseerde segregasie en afsonderlike ontwikkeling - laasgenoemde is soms getipeer as groot- en kleinapartheid - is vervang met 'n nuwe ideologiese raamwerk afkomstig uit 'n rewolusionêre tradisie (die Nasionaal Demokratiese Rewolusie-idee). Die toepassing hiervan is beter bekend as politieke transformasie. Sedert 1994 is hierdie ideologie van transformasie (streng gesproke transformatisme $)^{1}$ gebou op die teenpool van dít wat met die koloniale en apartheidsverlede geassosieer is. Sentraal binne hierdie idee-raamwerk (of ideologie), is die volslae omkering van die koloniale en apartheidsorde en die bevordering van wat voorgehou word as verenigend, nierassig, nieseksisties en ontwikkelingsgerig. Die fokus is gerig op die bevoordeling of bemagtiging van die slagoffers van die verlede - meestal mense wat tydens apartheid veronreg is (ANC 2017:1-22).

Soos dikwels gebeur met dergelike sosiogeniëringsprojekte waar omvangryke sosiale en politieke veranderinge aangedurf word, stem die uitkoms glad nie ooreen met die oorspronklike bedoeling daarvan nie. Utopiese ideale is moeilik te versoen met die politiese, ekonomiese en maatskaplike werklikheid. Trouens, soms word juis die omgekeerde bereik, soos in die geval van Ujamaa-sosialisme in Tanzanië tydens die sewentigerjare onder Julius Nyrere, en die radikale grondonteiening in Zimbabwe sedert 1999 - albei state is in die grootste armoede denkbaar gedompel (Duvenhage 2005B:1-19). Net soos die apartheidsbedeling (in eie reg 'n projek van sosiogeniëring) misluk het en uiteindelik radikaal hervorm moes word, blyk dieselfde tans die geval te wees met politieke transformasie in Suid-Afrika (1994-2021).

Byna net soos in die laat tagtiger- en negentigerjare, is politieke gesprekke nou weer in Suid-Afrika aan die gang in die soeke na 'n staatkundige orde wat die belange van die burgery voorop kan stel en verbeter ten opsigte van 'n toenemend onaanvaarbare status quo. Die huidige status quo is, soos apartheid, 'n produk van uiterste vorme van sosiogeniëring met eiesoortige waardes, norme en beginsels. Die uitkomste van die ideologie is telkens ver verwyderd van oogmerke wat oorspronklik gestel is! Trouens, die vooruitsig van 'n utopiese uitkoms (kenmerkend van die meeste ideologieë) is ook by transformatisme te bespeur in die strewe na 'n gelyke of egalistiese samelewing - meestal vêr verwyderd van die empiriese werklikhede, maar desondanks 'n instrument vir politieke mobilisasie (Duvenhage 2007A:377-403).

Hierdie studie stel as hipotese dat transformatisme (as politieke ideologie van toepassing vanaf 1994-1999) tot mislukking gedoem is, dat hierdie mislukking reeds duidelik waarneembaar is, en dat sodanige toedrag van sake verreikende gevolge inhou vir die Suid-Afrikaanse staat, die ekonomie en die samelewing. Trouens, daar sal geargumenteer word dat 'n transformatistiese ideologiese raamwerk alreeds aanleiding gegee het tot grootskaalse politieke, ekonomiese en sosiale verval en agteruitgang, met negatiewe uitkomste vir sowel die SuidAfrikaanse staat as die samelewing in die geheel. So beskou, lyk dit asof die uitkoms van hierdie ideologie feitlik die omgekeerde is van die utopiese vooruitsigte van nierassigheid, nieseksisme, 'n reënboognasie, eenheid en ontwikkeling. Anders gestel: die toepassing van gepaardgaande beleid vir die uitvoering van transformatisme het - anders as die verwagting - a-normatiewe, negatiewe gevolge.

Weens die radikale aard van "transformasie", soos tans toegepas in Suid-Afrika, is dit toepaslik om eerder soos Malan $(2012,2014,2019)$ van "transformatisme" te praat. Albei hierdie terme word afwisselend in hierdie studie gebruik 
Dit is duidelik dat die Suid-Afrika van 2021 tans diep verdeeld, polities onstabiel, rasgedrewe en rasgedefinieer, sosiaal gefragmenteer is en te staan gekom het voor enorme ekonomiese en finansiële hoofbrekens - die grootste sedert 1994, indien nie sedert die totstandkoming van die Unie in 1910 nie. Die onlangse uitbreking van geweld in KZN en Gauteng bevestig die omvang van die huidige krisis en die gepaardgaande vraagstukke.

Die doel van hierdie artikel is 'n kritiese ontleding van die politieke ideologie van transformatisme en die implikasies hiervan vir die huidige staatkundige bestel, sowel as die ekonomiese en samelewingsorde. Die navorsing is normatief van aard, aangesien 'n bepaalde staatsbeskouing, die Weberiaanse sterk staat en 'n bepaalde owerheidsvorm gesetel in dié van die regstaatidee of konstitusionele demokrasie, as uitgangspunt dien vir die beoordeling van die genoemde politieke ideologie, die toepassing en verreikende implikasies daarvan vir die staat, die ekonomie en ook die groter samelewing. Die navorsing is nietemin ook empiries, aangesien data en syfers gebruik word om die mate van politieke, ekonomiese en sosiale verval (as uitkoms van hierdie ideologie) aan te dui. Die studie is verkennend van aard en beoog om die geldigheid en korrektheid van bostaande hipotese, al dan nie, te ondersoek.

Fokuspunte van die studie sluit in:

- Konseptualisering en normatiewe vertrekpunte

- Sosiogeniëring (sosiale en politieke manipulering)

- Die Nasionaal Demokratiese Rewolusie-idee as leitmotif

- Transformatisme as ideologiese raamwerk

- Toepassingskontekste: polities, ekonomies en sosiaal

- $\quad$ Evaluasie en beoordeling

\section{KONSEPTUALISERING EN NORMATIEWE VERTREKPUNTE}

Transformatisme as ideologie en die praktiese voltrekking daarvan op beide die vlak van die staat enersyds en die owerheidsvorm andersyds word beoordeel. Hierdie twee kriteria kan verder gespesifiseer word, waaruit bepaalde norme en anti-norme afgelei sal word met die oog op verdere toepassing en operasionalisering.

Staat as norm: 'n Staat word gekenmerk deur 'n vaste geografiese territorium; 'n permanente owerheid, met ander woorde administrasie en bestuur wat onder gekoördineerde leierskap (regeerkundig van aard) funksioneer; wat bindende en afdwingbare besluite (".... those interactions through which values are authortitatively allocated for society" - aldus Easton 1965:21) kan neem; en as instelling beskik oor die monopolie ten opsigte van die aanwending van staatsmag of owerheidsgesag (Heywood 2002:86-88; Romano 1947). Bogenoemde staatskenmerke verduidelik egter nie die mate van funksionaliteit/wanfunksionaliteit van state nie. Uitgaande van die Weberiaanse vertrekpunt (1946), ondersteun deur Migdal (1988:21426) se staat-samelewingsbenadering, word die sterk staat (beide effektief en doeltreffend) as norm vir hierdie studie geneem. Hiervolgens is 'n staat volgens Weber (1964:154): “... a human community that successfully claims the monopoly of the legitimate use of physical force within a territory."

Staatsverswakking (die teenoorgestelde van 'n sterk staat) het te make met sake soos verlies van beheer oor die territorium; gebrekkige institusionalisering (dit wil sê swak regeerkundige, bestuursmatige en administratiewe praktyke); 'n onvermoë om die staat in 
stand te hou en die veiligheid van die burgery te verseker, en om noodsaaklike ontwikkeling te kan aanvoor. ${ }^{2}$

Die konsep van 'n verswakkende staat word vervolgens ook verbind met vorme van stelsel-entropie (Duvenhage 2020; Complex Systems 2019), en institusionele verval (Huntington 1968:1-8). Praetorianisme, oftewel die Praetoriaanse staat (die inmenging van militêre en veiligheidsinstellings in die politiek van die dag ter ondersteuning van 'n bepaalde bewind) is wat hier ter sprake is. (Dit is wat onlangs gebeur het met die ontplooiing van die polisie en die weermag in onlusgeteisterde gebiede in onder meer KwaZulu-Natal en Gauteng.) Dit moet beoordeel word teen die agtergrond van wat vroeër as staatsverswakking of owerheidsdisfunksie beskryf is. Hierdie toedrag van sake dui op 'n beperkte tot onvolledige vermoë om uitvoering aan beleids- en ideologiese vertrekpunte (eie aan transformatisme as ideologie) te gee. Die Weberiaanse denkbeeld (1964:154) van 'n sterk staat word gevolglik as norm geneem vir die beoordeling van staatkundige praktyke, met transformasie as die fokuspunt van staatsideologie (1994-2021), en beleid wat vanuit hierdie grondslag tot stand gekom het ter ondermyning van 'n sodanige normatiewe beskouing van 'n sterk staat.

Owerheisvorm as norm: Ten opsigte van die vorm van die staat (dit wil sê demokraties versus niedemokraties), is die normatiewe verbintenis tot die Rechtsstaat-idee, soos dit in die Duitse regswetenskap beslag gekry het of konstitusionele demokrasie met 'n baie soortgelyke betekenis. ${ }^{3}$ Die sentrale verstandhouding hieromtrent behels 'n staat wat berus op geregtigheid en integriteit, en wat op grond van Emmanuel Kant se terminologie rakende "Republik", verwys na 'n "union of men under law". Hierdie vorm van grondwetlike staat is in wese teen die arbitrêre gebruik en misbruik van staatsmag (soos geassosieer met vorme van polisiestate en ander vorme van niedemokratiese bedelings) gekant, en behels die volgende kernaspekte: ${ }^{4}$

1. 'n Grondwetlike staat met grondwetlike regte en waarborge vir die burgery.

2. Die bestaan van 'n onafhanklike burgerlike samelewing afsonderlik van, en in vennootskap met die staat.

3. Die skeiding van staatsmagte - uitvoerend, wetgewend en regsplegend - ingevolge 'n stelsel van wigte en teenwigte wat magsmisbruik deur die staat verhoed of ten minste beperk.

4. Duidelike grondwetlike en juridiese riglyne waarbinne staatsinstellings en ander instellings van die samelewing moet funksioneer en onderhou moet word.

5. Deursigtigheid van besluitneming en handeling ingevolge verantwoordbaarheid en aanspreeklikheid.

Vergelyk Geldenhuys (1999:38-46), Migdal (1988:214-26) en Zartman (1995:1-8) vir 'n meer volledige ontleding van die begrip verswakkende staat.

3 Die Rechtsstaat, 'n soms omstrede term, met soortgelyke eienskappe as die konstitusionele demokrasie, gewortel in gekwalifiseerde klassiek-liberale waardes, word as vertrekpunt geneem. Spesifieke waardes/norme wat vir doeleindes van die studie gebruik word, sluit in grondwetlike regering, konstitusionalisme, beperkte regering, skeiding van staatsmagte, oppergesag van die reg, verantwoordbare regering en die erkenning en handhawing van burgerregte en vryhede. Praktyke wat voortvloei uit die institusionalisering van die genoemde waardes en norme word as kriteria uitgesonder en as teenvoeter beklemtoon vir die institusionalisering van die gelykheidsnorm en sy toepassing (ekwiteit, swart bemagtiging, verteenwoordigendheid en korruptiewe staatspraktyke) as uitkoms van die ideologie van transformatisme soos hier beredeneer.

$4 \quad$ Vergelyk Stern (1984) vir sy uitgebreide ontleding van die toepaslike kenmerke van 'n Rechtsstaat of Malan (2019:7-17) se hantering van konstitusionalisme (sy voorkeurterm eerder as die Rechtsstaat-konsep) in hierdie verband. 
6. 'n Onafhanklike regbank en geregtelike hersiening ten opsigte van staatsoptrede, -handelinge en -besluite, waar en indien nodig.

7. Die hiërargiese ordening en plasing van wetgewing sodat ander wetgewing en besluite nie die grondwetlike staat en sy onderliggende filosofie, beleid en praktyke kan ondermyn nie.

8. Betroubaarheid en integriteit ingevolge handelinge, besluite en optredes, met verrekening van konteks, tradisie en agtergrond.

9. Proporsionaliteit ingevolge staatshandeling/optrede van die regime (gebruik van mag) ten opsigte van oortreding of wanoptrede.

Die Rechtsstaat-konsep soos hier bo omskryf, toon groot ooreenkomste met die liberaaldemokratiese vorm van regering, waarin sake soos grondwetlike regering, die oppergesag van die reg, verantwoordelike en verteenwoordigende regering, asook die erkenning en handhawing van burgerregte en vryhede beklemtoon word (Heywood 2002:72-74). Bogenoemde word as normatiewe vertrekpunt geneem en dien as grondslag vir die beoordeling van transformatiewe praktyke binne die huidige staatkundige bestel in Suid-Afrika.

Magstate (in teenstelling met regstate) word op hulle beurt gekenmerk deur praktyke wat dikwels lynreg bots met eienskappe van die Rechtsstaat soos hier bo aangedui. 'n Kenmerk wat soms met magstate verbind word (en ook kenmerkend is van die huidige Suid-Afrikaanse staat sedert sy totstandkoming), is "sosiale en politieke manipulering" (sosiogeniëring). Hierdie aspek word verder ontleed om 'n beter begrip te kry van die huidige stand van die SuidAfrikaanse politiek en die praktyk van politieke transformasie wat sedert 1994 hier neerslag gevind het.

\subsection{Sosiogeniëring}

Die Nederlandse industrialis JC van Marken het die konsep soisiogeniëring (in Engels vertaal as "social engineering") in 1894 bekend gestel op grond van die veronderstelling dat, net soos 'n samelewing tegniese kundiges benodig om tegniese kwessies te hanteer, "sosiogeniëringsdenkers" benodig word om sosiaal-maatskaplike kwessies aan te pak en daarmee te handel. Reeds in 1905 het die Duitse sosioloog Ferdinand Tonnies (The Present Problems of Social Structure 1905), beklemtoon dat sosiale manipulering op grond van data en syfers gebruik moet word om die samelewing progressief te verander ten einde ontwikkeling te bevorder en uitdrukking te gee aan waardes soos vryheid, voorspoed en geluk, gemeet volgens utilitaristiese bepalings. (Utilitarisme is die polities-etiese uitgangspunt dat alle politieke handeling die grootste moontlike geluk vir die grootste aantal mense moet verseker.)

Binne 'n breër verwysingsraamwerk kan sosiogeniëring voorgehou word as 'n vorm van sentrale beplanning ("top-down") om sosiale verandering te probeer bewerkstellig deur regulatief die gedrag en ontwikkeling van die samelewing te bestuur en ook te beheer. Die koms van ideologie en sy politieke toepassing op die massasamelewing (massamedia; propaganda; die oorvereenvoudiging van soms ingewikkelde sosiaal-maatskaplike kwessies), het gelei tot wat voorgehou kan word as die "politieke ingenieurs", met betrekking tot sosiale en politieke manipulering, ideologie, die raamwerk vir sosiale en politieke manipulering, omskryf as: "a belief system by virtue of being designed to serve on a relatively permanent basis a group of people to justify a reliance on moral norms, and a modicum of factual evidence and self-consciously rational coherence the legitimacy of the implements and technical prescriptions which are to ensure concerted action for the preservation, reform, destruction or reconstruction of a given order" (Seliger 1976:120). 
In sy bekende werk The open society and its enemies (volume 1, The Spell of Plato, 1945), onderskei Karl Popper tussen "demokratiese sosiogeniëring" en "utopiese sosiogeniëring". Waar eersgenoemde meer geleidelik toenemend probeer om 'n samelewing te verbeter (meestal demokraties gefundeerde verandering), is laasgenoemde snel, idealisties en daadkragtig en dikwels sterk ideologies geïnspireer. Popper (1945) onderskei in hierdie verband soos volg: "It is the difference between a reasonable method of improving the lot of man, and a method which, if really tried, may easily lead to an intolerable increase in human suffering [...] wherever it has been tried [the Utopian social engineering] has led only to the use of violence in place of reason ...".

Voorbeelde van utopiese sosiogeniëring en/of pogings in hierdie verband, sluit in die Sowjet Unie se poging tot die skepping van die "new Soviet man" tydens die twintigerjare (inbegrepe die vyfjaarplanne van Stalin); die Nazi-bewind in Duitsland (1933-1945); die Chinese "Great Leap Forward" (1958-1961), en die Kulturele Rewolusie (1966-1976), asook die Khmer Rouge se "Deurbanization of Cambodia" (1975-1979). Ander voorbeelde van sosiale en politieke manipulering sluit in die pogings tot etniese integrasie in Singapoer; Ujamaa-sosialisme tydens die sewentigerjare van die vorige eeu in Tanzanië, en grondhervorming in Zimbabwe sedert 1999 (Wikipedia, 2021). Telkens het soiogeniëringspogings uitgeloop op die verstaatliking van die samelewing (met ander woorde meer mag en bevoegdheid aan staatsinstellings), wat in skrille kontras staan met konstitusionele en Rechtsstaat-praktyke soos vroeër beklemtoon (Malan 2012:142-153;2014:462-480). Transformatisme pas by uitstek in die bogenoemde patroon.

In 'n Suid-Afrikaanse konteks kan koloniale praktyke, veral die Britse model wat wêreldwyd toegepas is, asook die beleid en toepassing van die apartheidstaat vanaf 1948 tot 1994, as vorme van sosiogeniëring voorgehou word. Hierdie raamwerk en perspektief vind tans ook neerslag in politieke transformasie in Suid-Afrika, met as grondliggende politieke ideologie die konsep van 'n Nasionaal Demokratiese Rewolusie (NDR).

\subsection{Die Nasionaal Demokratiese Rewolusie-idee as leitmotief}

Die ANC se handboek vir politieke verandering, Strategy and Tactics (2007:21), beskryf die NDR as: "a process of struggle that seeks to transfer power to the people and transform society into a non-racial, non-sexist, united, democratic one that changes the manner in which wealth is shared, in order to benefit all the people". Die uitgangspunt is dat Suid-Afrika "colonialism of a special kind" verteenwoordig, wat verwys na die land se unieke koloniale en apartheidsgeskiedenis en wat ingevolge 'n program van radikale politieke, sosiale en ekonomiese verandering getransformeer moet word om 'n nierassige, nieseksistiese, demokratiese en ekonomies volhoubare samelewing te bewerkstellig (vergelyk ANC 2017:1-5).

Ooreenkomstig hierdie denkpatroon (soos veranker in Marxisties-Leninistiese, Maoïstiese en ander vorme van rewolusiedenke), is daar drie fases van die rewolusie, naamlik die politieke oorname (beheer oor die regering en die groter regime); ekonomiese transformasie (staatsbeheer oor produksiefaktore naamlik grond, kapitaal, arbeid en ondernemerskap), en sosiale transformasie, met as uitkoms 'n samelewing waarin almal gelyk is (ANC 2017:4).

Op grond van hierdie prosesmatige beskouing van rewolusie, is die politieke kompromis van 1994, soos beliggaam in die Grondwet van 1996, bloot 'n taktiese deurbraak en moes dit die weg voorberei vir die suksesvolle volvoering van al drie fases van die volledige rewolusie. Daarom is die Grondwet van Suid-Afrika - ooreenkomstig hierdie ideologiese denkpatroon - net instrumenteel tot die voltrekking van bogenoemde fases, maar nooit belangriker as die 
verwesenliking van die rewolusionêre ideaal as sodanig nie. Die NDR en sy toepassing ingevolge transformasie is dus nie ondergeskik aan die Grondwet nie, maar juis superieur en moet uitgevoer word onder die wakende oog van die voorhoede-party, die ANC, wat die nodige regeerkundige en politieke leiding in hierdie verband moet verskaf. In sekere opsigte is die ANC en Luthuli-huis volgens hierdie denkpatroon daarom ook bo die reg verhewe, iets wat die ANC se hantering van korrupte leiers soos Ace Magashule en Jacob Zuma verklaar. Hierdie beskouing vind praktiese neerslag in die toepassing van die transformasie-ideologie, oftewel die praktyk van trasformatisme.

\subsection{Politieke transformasie as ideologiese denkraamwerk}

Politieke transformasie as uitkoms van 'n rewolusionêre politieke ideologie (die NDR) kan voorgehou word as die snelle, progressiewe, omvangryke en fundamentele politieke, ekonomiese en sosiale verandering van die staat en samelewing (voortspruitend uit ' $n$ onaanvaarbare verlede), wat die vorm aanneem van sentrale beplanning (sosiale manipulering en politieke beplanning en manipulasie), hegemonies bedryf deur 'n politieke elite met klem op die bestuur van verandering en die konflikte wat daarmee saamhang (Duvenhage 2005A:11; 2005B:1-17). Soos wat die geval is met alle ideologiese raamwerke is transformatisme idealisties en utopies, veral ten opsigte van fase 2 en 3 van die NDR, naamlik die herverdeling van produksiefaktore en die bereiking van 'n gelyke samelewing ooreenkomstig Marxistiese en sosialistiese beginsels. ${ }^{5}$ Transformasie word voorts aan die hand van die volgende kenmerke ontleed:

\subsubsection{Reaktiewe verandering}

Die regverdiging vir transformatiewe verandering setel in 'n onregverdige en nieregmatige verlede, waarin die rol van kolonialisme en apartheid deurslaggewend was. Alle beleid en gebruike wat verband hou met koloniale en apartheidspraktyke moet daarom met wortel en tak uitgeroei word en in sommige opsigte selfs tot misdaad teen die mensdom verklaar word. In reaksie op koloniale en apartheidspraktyke is die strewe nou 'n verenigde, nierassige, nieseksistiese, demokratiese en ontwikkelingsgerigte samelewing - die teenpool van bogenoemde. Hieraan is aktief sedert 1994 beslag gegee.

\subsubsection{Progressiewe verandering}

Die vestiging van demokratiese instellings en praktyke wat op verteenwoordigendheid aanspraak kan maak, moet voorrang geniet, met as uitkoms 'n nierassige, demokratiese bedeling. Tesame hiermee word vooruitstrewendheid, volhoubaarheid en ontwikkelingsgeoriënteerdheid (die gedagte wat aan 'n ontwikkelingstaat verbind kan word) as ekonomiese grondslag in werking gestel (ANC 2017:5). Die uitskakeling van armoede en alle vorme van ongelykheid is 'n prioriteit en moet beslag gee aan 'n egaliserende samelewing - die finale uitkoms van die NDR.

Vergelyk Duvenhage (2007:377-403) vir'n ontleding van transformatisme as 'n politieke ideologie. 


\subsubsection{Die egaliserende samelewing}

Gelykheid ingevolge die idee van 'n gelyke samelewing word verhef tot die allesoorheersende of dominante waarde binne hierdie ideologie. Nie gelyke geleenthede nie, maar gelykheid (egaliteit) met betrekking tot politieke, sosiale en ekonomiese status word bepleit (Malan 2019:195-200). Selfs vryheid word ondergeskik gestel aan gelykheid, daarom moet die samelewing op alle vlakke (en ten opsigte van alle strukture) die demografie van die samelewing en in besonder die rasverskeidenheid en verwante gewigte weerspieël. Radikale "chirurgie" (ingryping) is daarom nodig om die nuwe samelewing en staatkundige orde te bou en te ontwikkel, en moet dus deeglik beplan word.

\subsubsection{Beplande verandering}

Eie aan ideologiese raamwerke met sosiogeniëring as uitgangspunt, staan sentrale beplanning, koördinering, beleidsformulering, strategiese beplanningsraamwerke, reëls, regulasies en verordeninge voorop. Politieke transformasie, voortspruitend uit die NDR, is geen uitsondering nie. Dit word doelgerig beplan aan die hand van sentrale dokumente soos die Vryheidsmanifes; Strategy and Tactics; die 1996-Grondwet (soos wat dit transformatief vertolk en beleidsmatig toegepas word) en wetgewing wat in hierdie verband tot stand gekom het, asook besluite en resolusies wat aanvaar is tydens die Nasionale Konferensies van die ANC. Hiervolgens word gebiedende raamwerke, reëls en regulasies op die burgery afgedwing (sosiale en politieke manipulering) - 'n werkswyse wat wesenlik afwyk van wat vroeër as die Rechtsstaat en die beginsels wat dit onderlê, getipeer is. In wese is die oogmerk hiervan omvattende en uitgebreide sosiogeniëring as uitkoms van die vooropgestelde rewolusionêre ideaal waarin die voorhoedeparty (lees die ANC) 'n kernfunksie moet vervul met betrekking tot regeerkunde, oorsig en uitvoering, waarvoor die staat sy vermoëns en bekwaamhede gebruik en soms misbruik. Hierin is een van die grondoorsake van endemiese korrupsie gevestig - waarna soms ook verwys word as staatskaping.

Partylojaliste (kaders) word aangestel en gebruik om toe te sien dat beleidsraamwerke, besluite en resolusies doelmatig toegepas word, oortredings aan die kaak gestel word, en toepaslike optrede gehandhaaf word. In besonder moet gefokus word op die sondes van die apartheids- en koloniale verlede en oortredings (optrede en praktyke) wat daarmee verband hou.

Die fokus is nie net die staat as sodanig nie, maar die burgerlike samelewing in al sy fasette, naamlik ekonomiese aktiwiteite, sport, onderwys, woongebiede, ensovoorts. Die wesenlike onderskeid tussen staat en burgerlike samelewing ('n kernaspek van die Rechtsstaatkonsep) word oortree en onder die vaandel van die ideologie word daar soms diktatoriaal (niedemokraties, veral polities gesproke) en selfs totalitêr (niedemokraties veral wat betref verstaatliking van die samelewing) gehandel - dikwels in die fynste besonderhede beplan en gedokumenteer. Die keuse van taal op universiteitsvlak en nou ook op skoolvlak in 'n poging om alle staatsgefinansierde onderriginstellings eentalig Engels te bedryf, ongeag die veronderstelde gelyke en amptelike aansien van 11 tale, is maar een voorbeeld hiervan. ${ }^{6}$ Die

$6 \quad$ Vergelyk Malan $(2011: 387-407 ; 2019 ; 127-129)$ vir die uitwerking van die toepassing van transformatisme op die status en beoefening van die 11 amptelike tale en veral die onderskeid tussen amptelike status en gelykheid van aansien wat onderskei word en as 'n ideologies gedrewe verwringing geïnterpreteer kan word. 
rol van demokraties verkose skoolbeheerliggame word tans gewysig om inklusiwiteit, met eentalige onderwys as uitkoms, te probeer bewerkstellig.

Om hierdie sosiaal-politieke plan uit te voer, is uitgebreide strategiese beplanning (formulering, implementering en evaluasie) noodsaaklik en moet die ideaal van rewolusie via transformatiewe praktyke in werking gestel word.

\subsubsection{Strategie en uitvoering}

Strategiese beplanning is die organisatoriese bestuur (die staat, met die voorhoede-party of ANC as regering), waar strategiese prioriteite (politieke transformasie en veral verteenwoordigendheid as vertrekpunt), energie en hulpbronne gemobiliseer, gekoördineer en gefokus word met die oog op die uitbouing van die kernbesigheid (die NDR). Die klem val op die staat, die party, die samelewing, die ekonomie asook die internasionale gemeenskap, waar die bereik van 'n nierassige, nieseksistiese, demokratiese, volhoubare en egaliserende samelewing as uitkoms gestel word.

In die uitvoering van 'n strategie is die sogenaamde balansering van kragte ("balance of forces") van kritieke belang, wat deeglik onderhandel moet word voordat besluite geneem en toegepas word. Soms mag dit selfs nodig wees om ter wille van die rewolusie (lees die ideale van die NDR) toegewings teenoor die vyand te maak. Die kernvraag, soos gestel deur die ANC (2017:5), is: "Did the forces of change accurately read the balance of forces; and have they responded appropriately to this balance?" Hiervolgens is die Grondwet van 1996 nie onveranderlik nie en bloot ' $\mathrm{n}$ baken onderweg na die verwerkliking van die "National Democratic Society" as uitkoms van die NDR.

Ten opsigte van die formulering van die strategiese doelstellings en doelwitte is reeds heelwat geskryf, daarom val die klem verder op die implementering en evaluasie van hierdie strategiese oefening.

\subsubsection{Implementering en evaluasie}

Die verwerwing van politieke beheer oor die regering, owerheidsinstellings en uiteindelik die staat, verskaf die nodige grondslag vir verdere beheer wat uitgebrei word ten opsigte van die ekonomie en samelewing, volgens die onderskeie fases van die rewolusie, soos vroeër uiteengesit. Dit geskied deur strategiese beplanning, waarin die oorhoofse doelstellings (soos afgelei uit die NDR en makro-transformasieplan) uitgesonder en gespesifiseer word. Verteenwoordigendheid (praktiese oorname deur swart mense en marginalisering van minderhede) word geregverdig, en toegepas ingevolge die vertrekpunt van nasionale proporsionele verteenwoordigendheid (nie provinsiaal of plaaslik nie), en alle instellings binne die staat, ekonomie en burgerlike samelewing moet ooreenkomstig die formule gekloon word. ${ }^{7}$

Transformatiewe vordering sal gemoniteer word (die gebruik van telkaarte, ekwiteitsteikens en so meer), terwyl met oortreders op gepaste wyses gehandel sal word, byvoorbeeld deur boetes, uitsluiting van deelname en penalisering met die toekenning van kontrakte, selfs regsoptrede. Laasgenoemde is nog 'n praktyk wat wesenlik bots met die regstaatidee wat hier bo as norm voorgehou is.

\footnotetext{
7 Vergelyk Malan (2020:427-449) vir die toepassing van die idee van verteenwoordigendheid, 'n baie sentrale aspek van transformatisme as ideologie, die niekonstitusionele aard (of ten minste verwringing van sentrale grondwetlike vertrekpunte) asook die implikasies hiervan (politiek, ekonomies en maatskaplik).
} 
Samevattend het Suid-Afrika sedert 1994 'n demokratiese grondwet, maar een waarin 'n enkele party (self gedefinieer as 'n bevrydingsbewing) 'n rewolusionêre ideologie toepas wat direk bots met kernbeginsels van die regstaatidee, en waarin transformatiewe beleidsrigtings en die toepassing daarvan telkens diskriminerend van aard is. Selfs met die beskikbaarstelling van Covid-19-hulpfondse is riglyne van swart ekonomiese bemagtiging (SEB) gevolg, en ongeag beloftes deur die president, was korrupsie aan die orde van die dag - selfs in sy eie kantoor (De Vos 2020).

Wanneer verder in ag geneem word dat die huidige bedeling heelwat kenmerke van 'n verswakkende en selfs korrupte staat bevat, raak bogenoemde selfs meer problematies (vergelyk in dié verband Gumede 2021:24; Myburg 2019; Schüssler 2020; Eunomix 2020; Johnson 2019). Hierna kan ook verwys word as die de facto-staat - dit wil sê die harde werklikheid op voetsoolvlak, nie dít wat as normatiewe grondslag voorgehou word nie.

Ten opsigte van die de facto-staat is 'n sterk ideologie, 'n verswakkende staat, en toenemende sosio-ekonomiese en maatskaplike uitdagings onderling samehangend. Die impak van 'n rewolusionêre ideologie binne die raamwerk van 'n verswakkende en selfs korrupte staat, en die sosio-ekonomiese en maatskaplike implikasies vir die burgery, vorm die kern van verdere ondersoek. Soos vroeër in die hipotese gestel, het die ideologie van transformasie en die implementering hiervan verreikende implikasies vir die staat, die ekonomie asook die groter samelewing. Hierdie aspekte word vervolgens toegelig.

\section{TRANSFORMASIE SOOS TOEGEPAS: IMPLIKASIES VIR DIE STAAT, EKONOMIE EN SAMELEWING}

Wat die toepassing van transformasie betref, is dit duidelik dat 'n rewolusionêre ideologie volgens die kriteria van Seliger (1976:120) die riglyn is, waarin politieke en sosiale manipulering in ooreenstemming met Popper (1945) se "utopian social engineering" ter sprake is. Die klem val nou verder op die voltrekking van hierdie makro-ideologie ingevolge die uitvoering en implementering, asook implikasies daarvan vir die staat, ekonomie en samelewing.

\subsection{Die staatkundige konteks}

'n Radikale ideologie soos politieke transformasie veronderstel sosiale en politieke manipulering tesame met 'n "sterkstaat" (Weberiaans gedefinieer), om op 'n beplande en intervensionistiese wyse politieke, sosiale en ekonomiese verandering ooreenkomstig gestelde doelstellings daadwerklik te bevorder (Human 1998:23-41). Dit veronderstel 'n sterk staat, maar die teenoorgestelde is veel eerder hier aan die orde.

\subsubsection{Staatkundige en institusionele verval}

Kenmerke van 'n verswakkende staat, tesame met patrone van institusionele en politieke verval, blyk tans duidelik (Gumede 2020:24; Duvenhage 2016:905-937; 2020A:137-157). Hiervan getuig swak grensbeheer (vergelyk Lesotho, Zimbabwe, Mosambiek en Swaziland); disfunksionele owerheidstrukture, byvoorbeeld plaaslike regeringstrukture waarvan $80-90 \%$ disfunksionaliteit ervaar en sommiges heeltemal in duie gestort het, met toenemende diensleweringsproteste; endemiese korrupsie wat in uiterste vorm as "staatskaping" bestempel word (Duane 2017); wanfunksionele semistaatsinstellings, waaronder ESKOM, Transnet, die Poskantoor, Krygkor, en die SABC. 


\subsubsection{Interne ANC- en regeringskonflik}

Transformasie as 'n strategiese beplanningsoefening veronderstel ' $n$ strategiese bestuurskern, wat in hierdie geval die ANC (en sy strategiese vennote) is. Hulle vervul as voorhoede-party hierdie rol, soos uiteengesit in die dokument Strategy and Tactics. As gevolg van 'n kombinasie van faktore waaronder faksiegevegte, swak leierskap, en verskillende vertolkings van die toepassing van die NDR, is die ANC uiters kwesbaar om hierdie leierskaprol te vervul (Duvenhage 2016:905-937; 2020:151-153; Johnson 2019; Gumede 2021).

Daarteenoor volg die Ramaphosa-groepering 'n meer gematigde grondwetlike benadering. Die Radical Economic Transformation Group (RET) is ingestel op sake soos versnelde grondhervorming en selfs nasionalisering van grond; die nasionalisering van die SuidAfrikaanse Reserwebank; die vestiging van die Nasionale Gesondheidsversekeringstelsel, en vorme van armoedeverligting. Die kern van hierdie groepering word nietemin ook verbind met staatskaping en sluit mense in soos Jacob Zuma, Ace Magashule, Supra Mahumapelo, Tony Yengeni, Brian Molefe en Arthur Fraser. Hierdie groepering (die RET-groep) funksioneer op Mafia-agtige wyse en geniet populêre steun. Soos gestel deur William Gumede (2021:24): "Some of SA's state agencies are also run by small groups of powerful SA comrades, operating outside the law, accountable to no-one, and making these agencies no-go zones for democratic oversight."

'n Derde groepering (soms minder openlik waarneembaar), waarby individue soos David Mabuza en Paul Mashatile betrokke is, kompliseer die situasie nog verder. Die opbou na die Algemene Raadsvergadering van die ANC later vanjaar sal waarskynlik die konflik op die spits dryf. Ongeag die afspeel van die konflik en wie in beheer van die voorhoede-party gaan bly, is dit 'n situasie waarin daar nie doelmatige leiding gegee kan word met die toepassing van transformasiegerigte projekte op strategiese vlak nie. Gumede (2021A:24) vat die leierskapskrisis binne die ANC soos volg saam: "Mirror, mirror on the wall, who is the real leader of us all? In these trying times, SA needs one confirmed leader and one seat of power, not a parallel de facto 'Mafia boss' in Nkandla."

Samehangend met die verswakkende staat en patrone van institusionele en politieke verval, laat dit ernstige vraagtekens oor die suksesvolle toepassing van sosiale en politieke manipulering (sosiogeniëring) ten opsigte van transformatiewe beplanning. Soos met die toepassing van klein en groot apartheid, flikker die rooi ligte vir die huidige transformasie-oefening. Polities gesproke dui sterk getuienis daarop dat die Nasionale Transformasieprojek die belangrike gevaartekens miskyk en dat die spreekwoordelike skip besig is om op die rotse te loop.

\subsubsection{Staatskaping en endemiese korrupsie}

Korrupsie verwys na die misbruik van gesag/mag (staats- of openbare gesag), om private voordeel (hoe ook al gedefinieer), te verseker. In die strafreg word korrupsie gedefinieer as: "Anybody who (a) accepts any gratification from anybody else, or (b) offers or gives any gratification (benefit) to anybody else in order to influence the receiver to conduct herself or himself or itself in a way which amounts to the unlawful or irregular exercise of any duties, commits corruption" (Snyman 2008:411).

Staatskaping is 'n sistemiese vorm van korrupsie waarin private belange op 'n georganiseerde wyse besluite van die regering (regime) en owerheid beïnvloed, tot die voordeel van beide partye. Formele owerheids- en regeringsprosesse en -prosedures (wette, norme en konvensies) word deur netwerke en patronaatskappe gemanipuleer tot die voordeel van private en regeringsbelangegroepe (Duane 2017). 
Ten tyde van regime-veranderings (byvoorbeeld die val van kommunisme in die Europese Oosbloklande, of die derde golf van demokratisering), en/of wanneer 'n nuwe stelsel lae vlakke van institusionalisering ervaar, is sodanige politieke stelsels kwesbaar vir endemiese korrupsie en staatskaping. Die beëindiging van apartheid en die totstandkoming van die nuwe demokrasie (met die ideologie van politieke transformasie), het sodanige geleentheid geskep.

Die omvang van staatskaping (veral nadat Jacob Zuma die bewind in 2009 oorgeneem het), word uitgebreid in verskeie publikasies behandel, waaronder Shadow state: the politics of state capture (Swilling \& Chipson 2018); The President's Keepers - those keeping Zuma in power and out of prison (Pauw 2017); Gangster state -unraveling Ace Magashule's web of capture (Myburgh 2019); en How long will South Africa survive - the looming crisis (Johnson 2015).

In 2017 het Pravin Gordhan tydens 'n aanbieding deur die UCT Bussiness School byvoorbeeld die waarde van staatskaping op R250 miljard geskat, terwyl die Daily Maverick die finansiële waarde daarvan (in die periode 2015-2019) op sowat R1,5 triljoen geskat het (Merten 2019).

Uitgebreide getuienis voor die Zondo-kommissie het die afgelope tyd perspektiewe van bostaande werke met kragtige getuienis gerugsteun, en daar is besef dat bogenoemde maar net die oortjies van die spreekwoordelike seekoei was. Die termyn van die kommissie is onlangs verleng sodat meer diepliggende ondersoek gedoen word en die verslag afgehandel kan word. Dit was veral die rol wat die Staatsveiligheidsagentskap in dié verband gespeel het (en die bestaan van parallelle strukture wat die vorige president se persoonlike belange beskerm het), wat die huidige bestel tot in sy wese geskok het. Getuienis is gelewer ten opsigte van die misbruik van die Intelligensiedienste vir persoonlike en private gewin ten opsigte van parallelle strukture in diens van die president (Zuma); staatsgesanksioneerde projekte teen politieke teenstanders binne en buite die ANC; die kanalisering van fondse tot voordeel van die ANC se Nasionale Konferensie van 2017; die voorsiening van wapens aan misdadigers, en omkoopgeld vir regters en joernaliste om bepaalde uitkomste te beïnvloed (The Africa Report 2021).

Dit is duidelik dat alle aspekte wat verband hou met 'n regstaatidee, oortree is en dat Suid-Afrika kenmerke toon van 'n Praetoriaanse (Huntington) sowel as 'n verswakkende staat (Migdal) - dus die teenoorgestelde van die Weberiaanse sterkstaat soos hier bo uiteengesit. Die ideale van politieke transformasie het daarom vasgeval in 'n moeras van korrupsie, staatskaping en politieke verval - in algehele teenstelling met die ideologiese oogmerke wat aanvanklik in die vooruitsig gestel is.

Vanuit ' $n$ staatkundig-politieke perspektief is 'n sodanige uitvoering van transformasie nie haalbaar nie, veral gegewe die gebrekkige kapasiteit as 'n uitvloeisel van kaderontplooiing en die daarmee gepaardgaande vlakke van endemiese korrupsie wat private belang bo algemene belang stel - aspekte wat indruis teen die beginsel van egaliteit en wat die ideale transformasie soos beoog deur die NDR laat versand het in transformatisme.

\subsection{4 'n Verslegtende veiligheidsituasie}

Die politieke en ekonomiese ontledingsgroep Eunomix: Business \& Economics (2020:5-6) het onlangs voorspel dat Suid-Afrika teen 2030 'n "mislukte staat" soos Nigerië, die Ivoorkus en Bangladesj gaan wees. Gemeet aan regeerkundige kriteria word melding gemaak van SuidAfrika se terugsakking betreffende lewensgehalte en -standaard, ekonomiese groei, asook breekbaarheid ("fragility"). Samehangend hiermee is Suid-Afrika deur die Global Peace Index 
(2018) 127ste uit 163 state geplaas, saam met state soos Liberië, Venezuela, Sirië, Irak en Afghanistan.

Die verslegtende veiligheidsituasie word ook duidelik uit die steeds groeiende getal onwettige immigrante, geskat op tussen 2,1 en 4 miljoen mense (Versluis \& de Lange 2019), wat Suid-Afrika binnestroom, asook die aanwesigheid van sowat 9000 geregistreerde private veiligheidsmaatskappye met 'n werksmag van sowat 500000 mense. Daarteenoor beskik die polisiemag oor net sowat 150000 beamptes en die Staande Mag bestaan uit 73844 lede (Krige 2019:1).

In navorsing word die voorwaarde vir 'n "revolusionêre staat" met 'n transformatiewe agenda gestel: " $\ldots$ only a strong state can shape a new society, as only a state with strong institutions can truly revolutionize society" (Human 1998:2). Suid-Afrika is tans ver verwyderd van wat voorgehou kan word as 'n "rewolusionêre staat" met die nodige kapasiteit om die NDR-ideale te kan uitvoer. Trouens, die onvermoë om transformasie te bewerkstellig en die wyse waarop dit geïmplementeer word, lê ten grondslag aan die inploffing van staatsinstellings en algehele staats- en institusionele verval.

\subsubsection{Die inploffing van die strafregstelsel}

Binne die raamwerk van 'n regstaat is die oppergesag van die reg, asook die suksesvolle toepassing daarvan, ononderhandelbaar. Kinnaird (2018) stel egter dat: "The criminal justice system is broken and it can't be fixed." Hierdie stelling word bevestig deur die Jaarverslag van die Nasionale Vervolgingsgesag, wat daarop wys dat wet en orde tydens 2018/9 in werklikheid in duie gestort het. In vergelyking met die vorige jaar (2017/18) was daar 'n afname van 10,7\% sake wat die NVG bereik het; 103700 sake is bloot onttrek, en die uitset van howe was sowat 14\% laer (Versluis \& De Lange 2019). Op grond van die bogenoemde verslag word gestel: "The greatly feared category of 'trio-crimes' - vehicle hijackings, home robberies and robberies at businesses - appears to go almost unpunished. According to police's annual report, 16026 vehicle hijackings were reported. In the same period the NPA managed to prosecute just 3\% of that number." Ten opsigte van huisrooftogte was die suksesfaktor $4,6 \%$, en rooftogte by besighede sowat 3\% tydens dieselfde jaar. Van die 52450 seksuele misdrywe tydens 2018/19 is slegs 4724 te boek gestel - sowat 9\% (Versluis \& de Lange 2019).

Dus word die "beste grondwet ter wêreld", waarin die oppergesag van die reg juis gewaarborg word, ondermyn deur 'n wanfunksionele Nasionale Vervolgingsgesag en 'n groter strafregstelsel gekenmerk deur korrupsie, kapasiteitsprobleme en aanvegbare uitsprake, waarvan die Shabir Shaik-aangeleentheid bloot een voorbeeld is.

Getuienis in hierdie verband is breedvoerig deur die Zondo-kommissie van ondersoek blootgelê, wat deel vorm van 'n groter poging van die kant van die Ramaphosa-regering om weer die strafregstelsel te bemagtig en Hoofstuk 9-instellings te herstel na afloop van die fase van staatskaping, wat hierdie instellings uiters kwesbaar en wanfunksioneel gelaat het.

Hierdie wanfunksionaliteit ondermyn die wese van wat vroeër binne regstaatverband as belangrik uitgewys is en ondermyn die wesenskern van transformatiewe optrede wat gebou is op die grondslag van 'n sterk, funksionele en normatief begronde staatsbestel.

Hierdie polities-staatkundige konteks getuig daarvan dat die hipotese van hierdie studie korrek is - die uitvoering van transformasie en die bereiking van verbandhoudende gestelde doelstellings is tot mislukking gedoem. Daarbenewens het die ideologie onderliggend aan transformasie die terrein voorberei vir nie net 'n "korrupte staat" nie, maar ook 'n "mislukte staat". 


\subsection{Die ekonomiese konteks}

Waar die eerste fase van die NDR op politieke oorname gefokus het, is die tweede fase gerig op die herverdeling van produksiefaktore, met name grond, kapitaal, arbeid en onderneming. Hierdie strewe is deel van die oorhoofse transformasiestrategie gerig op: "... a united, nonracial, democratic and prosperous South Africa". Die Nasionale Konferensie van die ANC in 2017 se tema was: Towards Unity, Renewal and Radical Economic Transformation (RET). Magashule (2018:1-8) beklemtoon die fokuspunt van die konferensie as die herstel van: “... the historical injustices of land dispossesion ..." en verder: “... (W)e shall pursue land expropriation without compensation as a matter of policy. [...] We shall give effect to this resolution in a matter that strengthens the agricultural sector, improves economic growth and addresses inequality and unemployment."

In skrille kontras met die goue jare van ekonomiese groei (1994-2007), het die situasie sedert 2008 dramaties begin verander en hierdie verslegtende situasie is vererger deur die verreikende implikasies van die Covid-19-pandemie. Die huidige stand van die Suid-Afrikaanse ekonomie kan in die volgende kernpunte opgesom word:

\subsubsection{Beperkte ekonomiese groei en stygende werkloosheid}

Sedert ongeveer 2015 het ekonomiese groei in Suid-Afrika dramaties begin afneem en negatiewe groeisyfers (soos gemeet per kwartaal, byvoorbeeld die eerste en derde kwartale van 2019), was aan die orde van die dag (Brink 2019:1-2). Tans verkeer die ekonomie in een van sy langste afwaartse siklusse sedert die Tweede Wêreldoorlog. Covid-19 het hierdie siklus vererger en die OLD Mutual Investment Group bereken dat die ekonomie met 7,3\% kan inkrimp, dat 'n begrotingstekort van meer as $15 \%$ ons voorland is, en dat staatskuld (as persentasie van die bruto binnelandse produk) tot meer as 80\% kan toeneem (De Lange 2019:1). Laasgenoemde syfer is onlangs bevestig deur ekonome wat selfs 'n somberder scenario in die vooruitsig stel. Katzenellenbogen (2020) vra selfs die vraag: "How close are we to economic collapse?"), terwyl Johnson (2015:161, 163, 175-192) se voorspelling dat Suid-Afrika geld sal moet leen van onder meer die Internasionale Monetêre Fonds waar blyk te wees, asook sy perspektief dat: "South Africa's slow-motion momentum towards a financial train crash has begun to speed up" (2019:1).

Waar werkloosheid in die eerste en tweede kwartale van 2020 onderskeidelik 23,3\% en $29,1 \%$ was, het dit in die derde kwartaal tot 30,8\% gestyg. Volgens die uitgebreide definisie van werkloosheid het dit in dieselfde periode op 43,1\% te staan gekom! In die loop van 2020 het die getal werkloses van sowat 4,3 miljoen tot 6,5 miljoen toegeneem (Winning 2020:1). Volgens Wicks en Ash (2020:23) kan tot 7 miljoen werksgeleenthede as gevolg van Covid-19 en die swak bestuur hiervan in die gedrang kom, met werkloosheid wat kan styg tot $50 \%$, en 'n ekonomie wat met tot $10 \%$ kan inkrimp. Groeiende werkloosheid hang saam met 'n tendens wat as de-industrialisering beskryf kan word en wat vervolgens behandel word.

\subsubsection{De-industrialisering}

Bogenoemde verwys na die inkrimping van die industriële vermoë van 'n staat of streek, met spesifieke verwysing na die nywerheids- en vervaardigingsbedryf. In 'n artikel getiteld: "Going backwards - the deindustrialization of the South African economy" (2019), wys Anthony Turton op die wyse waarop Suid-Afrika op die gebied van nywerhede en vervaardiging 
agteruitgegaan het - waar Suid-Afrika twee dekades gelede tegnologies gesproke op internasionale vlak mededingend was, was daar nie net 'n terugsakking nie, maar 'n inploffing in die betrokke bedryf (vergelyk Strachan (2017:1), en Van der Groenendaal (2017), vir soortgelyke perspektiewe).

Johnson (2015:146-174) se beskrywing: "The state's repression of economic activity", brei uit oor die inploffing van die mynbedryf, die ineenstorting van die vervaardigingsbedryf, en die uitdagings waarvoor die landboubedryf tans te staan kom. Ten opsigte van die mynbedryf, getipeer as "the great mining disaster"), stel Johnson dit (2015:155) soos volg: "Twenty years ago South Africa was regarded as having one of the most impressive mining regimes in the world. In 2012 the Frazer institute survey of mining countries rated South Africa 54th out of 93. In 2013 the rating fell to 64th. This is amazing when one considers that South Africa has the greatest treasure trove of minerals in the world." Soos Turton (2019), verwys ook Johnson (2015:158) na: “... the ANC government [that] has presided over an unprecedented period of de-industrialization".

\subsubsection{Groeiende skuldlas en die vlug van kapitaal}

Sedert die termyn van president Jacob Zuma het staatskuld die hoogte ingeskiet tot waar dit vandag meer as $80 \%$ van die BBP van die land beloop. Parsons (2020:1) reken dat Suid-Afrika op die huidige trajek teen 2023/4 die vlak van 'n soewereine skuldkrisis kan bereik, wat beteken dat bestaande skuld nie meer betaal sal kan word nie. Schüssler (2020) wys daarop dat SuidAfrika maandeliks tussen R60 en R65 miljard finansieel oorbestee - 'n tendens wat nie volhoubaar is nie. Heystek (soos aangehaal in Cameron 2021A), beklemtoon op sy beurt dat, ongeag die krisis van die Zuma-jare en die gepaardgaande assosiasie met korrupsie en staatskaping, en ten spyte van beloftes vir herinvestering in onlangse tye, daar tussen 1 Maart 2018 tot Desember 2020 sowat R250 miljard uit die land gevloei het.

\subsubsection{Verkleinde belastingbasis en populistiese projekte}

'n Kommerwekkende tendens oor ten minste die laaste dekade of langer, is wat voorgehou kan word as 'n krimpende en erg skeefgetrekte belastingbasis. Reeds in 2011-12 het Paul Joubert (2013) van Solidariteit se Navorsingsinstituut bevind dat slegs 3,3 miljoen mense $99,9 \%$ van die belasting betaal; 2,3 miljoen betaal $93 \%$; en so min as 1,5 miljoen betaal $84 \%$ van alle persoonlike belasting.

Persoonlike belasting maak sowat $38,3 \%$ van die huidige belastingbasis van die land uit, met sowat 22 miljoen geregistreerde belastingbetalers. Van hierdie 22 miljoen is net sowat 5 miljoen belastingbetalers. Steenkamp (2019:3) wys daarop dat, van die sowat 5,99 miljoen belastingbetalers in 2013/4, daar in 2016/7 slegs 4,89 miljoen oorgebly het - 'n vermindering van sowat 18,2\%. Steenkamp (2019:3) wys verder daarop dat die belastinglas per individu in dieselfde tydperk van R45 702 tot R65 601 toegeneem het - 'n toename van 43,5\%. Oor die laaste sowat 'n dekade het die belastingbasis (ongeag 'n snel groeiende bevolking) verder verklein en selfs nog meer skeefgetrek geraak, omdat al hoe minder belastingbetalers al hoe meer belasting betaal. Dit verskil wel van verkoopsbelasting wat meer inklusief is, maar ook negatief geraak word deur die swak ekonomiese groei oor die afgelope dekade en langer!

Negatiewe reaksie op hoë belastings ingevolge belastingboikotte (e-tol), belastingbetalers wat die land verlaat (volgens berekening 23000 per jaar - Bussinesstech, 2021), en die bereik van 'n belastingplafon ooreenkomstig die Laffer-kurwe (hoe hoër die belastingvlak, hoe kleiner 
die inkomste), is groot bedreigings vir 'n gesonde belastingsbasis. Buys (2020) verwys in hierdie opsig selfs na die: "rewolusie van die "rykes", en vat die problematiek soos volg saam: "Die rewolusie van die rykes lê nie in die toekoms nie; dit woed reeds - stil maar vernietigend. Suid-Afrika is reeds die grootste uitvoerder van werkskeppers, kundigheid en belastingbetalers. Dis 'n dubbele slag: die staat se inkomste neem af en die uitgawes aan armes se welsyn neem toe. Uiteindelik stort die staat in duie, sonder genoeg kundigheid en die geld om 'n moderne land te bedryf."

Hierteenoor staan die populistiese oriëntasie van die regering, met steeds groeiende getalle wat sosiale toelaes ontvang; die afskrywe van skuld (tussen R13 en R20 miljard private skuld is onlangs afgeskryf); die implementering van die Nasionale Gesondheidsversekeringskema, wat na bewering tot R450 miljard kan kos; versnelde grondhervorming en die koste-implikasies daarvan; en die groeiende staatskuld en skuld van instellings soos SAA, ESKOM, die Landbank, die Poskantoor, SABC, ensovoorts (vergelyk Johnson 2021).

Beperkte ekonomiese groei versus hoë vlakke van gemobiliseerde verwagtinge (die sogenaamde J-kurwe - Heywood 2002:218-219), in samehang met die inploffing van staatstrukture, skep 'n omgewing van onstabiliteit en potensiële onstabiliteit wat nie bevorderlik is vir groei en ontwikkeling nie.

\subsubsection{Botsende en ingewikkelde wetgewing}

Verswakkende state word dikwels gekenmerk deur uitgebreide en gedetailleerde wetgewing volgens die normatiewe staat, maar wat nietemin dikwels ontoereikend toegepas word in die empiriese staat (Duvenhage 2020A:137-157). Dit is presies die geval met transformasie in Suid-Afrika waar daar 'n ooraanbod van wetgewing is, maar die toepassing daarvan veel te wense oorlaat en dikwels die omgekeerde bereik van wat in die vooruitsig gestel is.

Die uitgebreide swartbemagtingswetgewing en ingewikkelde toepassing daarvan; arbeidswetgewing; wetgewing ten opsigte van ekwiteit, asook talle transformasiegerigte wetgewing, beklemtoon bogenoemde toedrag van sake.

Wanneer wetgewende raamwerke boonop probeer om populisties te wees deur byvoorbeeld die elite of sekere groepe ten koste van andere te bevoordeel, is die probleem nog groter. Die aanvaarding van talle populistiese besluite tydens die ANC se konferensie in 2017, is voorbeelde hiervan. Dit is veral die (beoogde) wysiging aan artikel 25 van die Grondwet (die eiendomsklousule wat die weg moet voorberei vir onteiening sonder vergoeding), wat tans op die voorgrond staan. Die implikasies van ingewikkelde en populistiese wetgewing sluit onder meer in:

- Onsekerheid ten opsigte van beleid en die gepaardgaande toepassingsraamwerke;

- 'n Gunstige teelaarde vir korrupsie en nepotisme en die bevordering daarvan binne 'n transformatiewe swartbemagtigingsraamwerk tot die vlak van staatskaping;

- Oormatige regulering en ander reëlings wat investeerders binnelands en buitelands afskrik;

- Die vlug van kapitaal (sosiaal en materieel);

- Die bevordering van diskriminasie (die omgekeerde van wat die ideologie in die vooruitsig stel), met wetgewing ten gunste van swartbemagtiging (BBBEE) en billikheid, en veral die toepassing daarvan, is die grondslag van die probleem. (Witmonopolie-kapitaal word as die oorheersende vyand voorgehou!) 


\subsubsection{Die Covid-19-dinamika}

Reeds voor Covid-19 was Suid-Afrika in 'n politieke, ekonomiese en maatskaplike krisis gewikkel (Johnson 2015, 2019). Die Covid-19-pandemie het hierdie krisis omskep in 'n sogenaamde "perfekte storm". Nie net gaan ekonomiese groei met omtrent 10\% inkrimp nie, maar daar word verwag dat tot 7 miljoen werksgeleenthede in gedrang kan wees (Wicks \& Ash 2020:23; Cameron 2020:1).

Die ironie van die situasie ten opsigte van Covid-19 was dat die regering met sy toekenning van hulp juis die geleentheid gebruik het om transformasie te bevorder, deurdat hulp en ondersteuning op grond van ras plaasgevind het; groot dele van die "transformatiewe kategorie" spesiale toelaes ontvang het (waarvan die tydperk boonop onlangs verleng is), en dat korrupsie ingevolge tenderprosesse wyd voorgekom het (Corruption Watch 2020; Merten 2019).

Uitgebreide korrupsie ten opsigte van die bestuur van die Covid-19-dinamika was ook aan die orde van die dag en die politieke bedeling het meer outoritêre eienskappe begin toon.

Waar die tweede fase van die NDR gerig is op die gelyke verdeling van produksiefaktore in 'n poging om ' $n$ vooruitstrewende samelewing te bevorder, word dit tans ernstig in die wiele gery deur strawwe ekonomiese realiteite, in samehang met swak regeerkundige praktyke (Gumede (2021A). Beperkte tot negatiewe groei oor die laaste dekade of meer; toenemende werkloosheid en armoede; 'n verkleinde belastingbasis en die "rewolusie van die rykes"; patrone van de-industrialisering; toenemende skuldlaste en die vlug van kapitaal, asook populistiese beleidsraamwerke en wetlike oorregulering maak die gestelde transformasiedoelwitte (soos onder meer beliggaam in die Nasionale Ontwikkelingsplan en ander raamwerke), onbereikbaar. Trouens, soos sake nou staan, gaan juis die omgekeerde bereik word en nog verder aangehelp word deur die koronavirus en die wyse waarop dit hier bestuur word. Ekonomiese werklikhede beklemtoon, in die hipotese gestel, dat transformasie voortspruitend uit die NDR, en wat daardeur in die vooruitsig gestel word, tot mislukking gedoem is. Nie net bevind Suid-Afrika hom tans in 'n ekonomiese krisis nie, maar ook in 'n finansiële en fiskale krisis. Soos gestel, is die uitkomste a-normatief, soos gemeet ingevolge die ideale verbonde aan die nasionale projek van transformasie, en instrumenteel tot politieke, ekonomiese en maatskaplike verval. Aan laasgenoemde word ten slotte aandag gegee.

\subsection{Die sosiaal-maatskaplike konteks}

As gevolg van die gekompliseerdheid van hierdie konteks word enkele sleutelsake uitgelig, in aansluiting by, en in samehang met die voorafgaande kontekste. Die Suid-Afrikaanse samelewing is Toffleriaans-gesproke (1998) tegelyk in drie rewolusies vasgevang, naamlik die agrariese (tradisionele grondbesit en grondhervorming), die industriële (mynbou, vervaardigingsektore en dienstesektore), en die postindustriële (inligting/kennis, kommunikasie en tegnologie) rewolusies. Dit maak die samelewing nie net uiters gekompliseerd nie, maar dinamies, onvoorspelbaar en soms lewensgevaarlik.

Suid-Afrika kan beskryf word as 'n uiters verdeelde samelewing, vasgevang in die gekompliseerdhede van drie rewolusies en hulle gepaardgaande uitkomste. Cronjé (2017:3961) verwys hierna as die "breakdown of South African family life". Samevattend word na enkele aspekte van hierdie ingewikkelde situasie verwys:

- Bykans 'n halfmiljoen mense is sedert 1994 in Suid-Afrika vermoor (Cronjé 2017:58).

Sowat 58,4 mense word daagliks vermoor (sowat $40 \%$ hiervan in die taxi-bedryf), en 115,8 verkragtings word per dag aangemeld (Baxter 2020). 
- Geweld kom voor in verskeie vorme soos diensleweringsproteste; arbeids- en gesinsgeweld; xenofobie; kulturele en rasgebaseerde konflik; vigilantisme; politieke sluipmoorde, en taxi-geweld wat in die algemeen bydra tot soms groot onstabiliteit en ontwrigting.

- Die aanwesigheid van wat Huntington (1968:72-92; 192-194; 198-237) "praetoriaanse samelewingstoestande" noem, in teenstelling tot "burgerlike samelewingstoestande", is tans prominent. Hiervolgens is dit 'n samelewing: “... which lacks law, authority, cohesion, and discipline and consensus, where private interests dominate public ones, where there is an absence of civic obligation and civic duty, where in short political institutions are weak and social forces strong" (Huntington 1965:416).

- Sowat 55\% van die bevolking (sowat 30 miljoen) lewe onder die armoedelyn van R992 per maand (Gous 2018:2). Die situasie versleg tans as gevolg van negatiewe ekonomiese groei en die impak van die Covid-19-pandemie.

- Gebroke gesinne, soos blyk uit die sowat 19 miljoen kinders uit huise waar 7,5 miljoen enkelouers het en 6,5 miljoen sonder enige ouers is (Cronjé 2017:39-61).

- Die ryk-arm-gaping (soos gemeet aan die Gini-kwosiënt) behels dat 1\% van alle burgers 70,9\% van rykdom besit en die onderste 60\% sowat 7\% (Gous 2018:2).

- Die verval van samelewingsinstellings waaronder skole, universiteite, gesondheidsinstellings en plaaslike regering in die algemeen. (Tot $80 \%$ van alle skole word as disfunksioneel geag.) (Duvenhage 2020A:154-156.)

- Toenemende misdaad teen die agtergrond van die inploffing van die strafregstelsel. Patrone van onstabiliteit en geweld verskaf 'n grondslag en gunstige groeibodem vir misdaadorganisasies, sindikate, Mafia-groepe en bendes, wat dikwels in samewerking met staatsinstellings funksioneer soos onder meer blyk uit getuienis gelewer voor die Zondo-kommissie, asook die talle polisiebeamptes wat gereeld by misdaad betrek word.

Die sosiale konteks het ingevolge maatskaplike uitdagings soos armoede, 'n kultuur van geweld, georganiseerde misdaad, die verval van samelewingsinstellings oor die afgelope dekade eerder "gedetransformeer" en nie getransformeer ooreenkomstig doelstellings van die ideologie nie. Waar transformasie inherent progressief van aard is, is wat ons hier waarneem, regressief en eerder sosiale en maatskaplike verval, soos weerspieël in samelewingstoestande wat tans heers. Die sosiaal-maatskaplike konteks, soos ondersteun deur huidige en te voorsiene politieke en ekonomiese gebeure, beklemtoon die feit dat politieke transformasie as uitkoms van 'n rewolusionêre ideologie tot mislukking gedoem is en dat hierdie mislukking reeds waarneembaar is, met verreikende implikasies vir die staat, ekonomie en groter samelewing. Pogings tot sosiale en politieke manipulering het as uitkoms sosiale en maatskaplike verval, en beklemtoon die perspektief van Johnson (2015:238): "What is now clear, just 20-odd years later and beyond any reasonable doubt, is that 'liberation' has failed, that the regime it has produced is quite incapable of governing South Africa as a free, democratic and functioning country."

\section{EVALUERENDE PERSPEKTIEWE}

Geen politieke denkpatroon (lees ideologie) is net negatief nie. Die ANC verklaar dikwels hul sukses met betrekking tot groter toegang tot dienste en dienslewering aan alle burgers, uitgebreide toekenning van maatskaplike en sosiale toelaes aan armes, swart bemagtiging, en die uitwissing van koloniale en apartheidspraktyke (hoe ook al gedefinieer), as hul bydrae tot 
'n beter samelewingsorde, ekonomiese en politieke bestel. Die balansstaat van sake beklemtoon egter dat die laste die bates letterlik en figuurlik ver oorskry. Baie hiervan het te make met die idealistiese en utopiese aard van transformatisme as ideologie enersyds en die totale onderprestering van staatsinstellings (die verswakkende staat) andersyds.

Net soos in die geval van ander ideologies gedrewe sosiogeniëring en polities manipulerende projekte, waarvan kolonialisme en apartheid minder volgroeide voorbeelde is, is ook politieke transformasie, voortspruitend uit die NDR, gedoem tot mislukking - 'n mislukking waarvan ons toenemend daagliks kennis neem. Hiervan getuig talle politieke tendense en patrone, onder meer vorme van politieke en staatkundige verval; ontoereikende grensbeheer; gebrek aan veiligheid en sekerheid; endemiese korrupsie en staatskaping, asook faksiegevegte onder politieke elite-groepe. Die ekonomie word gekenmerk deur lae tot negatiewe groeipatrone; toenemende skuld; patrone van disinvestering en die vlug van kapitaal; de-industrialisering; 'n proporsioneel verkleinde belastingbasis; onuitvoerbare projekte; oorregulering, en die beplande wysiging van artikel 25 van die Grondwet tesame met die implikasies hiervan vir privaat inisiatief, investering en ekonomiese en finansiële vertroue.

Op sosiale terrein is die vlakke van sosiale disintegrasie, patrone van geweld, armoede en swak dienslewering, inbegrepe onderwys en gesondheid, omstandighede wat dikwels eerder versleg as verbeter het deur die loop van die sowat 27 jaar van ANC-regering.

Die voorafgaande ontleding bevestig dat politieke transformasie soos toegepas in ooreenstemming met die rewolusionêre vertrekpunt van die NDR, gedoem is tot mislukking en ten grondslag lê aan patrone van politieke, maatskaplike en ekonomiese agteruitgang in Suid-Afrika. Die ideologie en die wyse waarop dit toegepas word, staan in skrille kontras teenoor die ideaal van 'n verenigde, nierassige, nieseksistiese, demokratiese en volhoubare samelewing.

Volgens normatiewe bepalings word die regstaat en sy onderliggende kriteria as vertrekpunt geneem, maar die toepassing daarvan is 'n rewolusionêre ideologie in aksie, wat letterlik elkeen van die duidelik aangeduide norme, soos veranker in die regstaatidee, oortree en prakties gesproke beslag gee aan 'n verdeelde, rasgedefinieerde, seksistiese samelewing wat dikwels liberaal-demokratiese praktyke vervang met endemiese korrupsie en patronaatskappe, wat boonop nie finansieel en ekonomies volhoubaar is nie.

Die hervorming, of selfs transformatistiese ingryping, is dringend nodig, met as voorvereiste 'n hersaamgestelde politieke spektrum waarin gematigdheid en hervorming, eerder as populisme en radikalisme, die botoon voer. Sodanige aanpassing is onvermydelik, maar die prys wat daarvoor betaal gaan word kan wissel. Myns insiens ontbreek die insig binne die ANC-leierskap (anders as wat die geval was met die Nasionale Party van destyds), om betyds die nodige hervormings te bewerkstellig. Die Hegeliaanse perspektief, naamlik dat die enigste les uit die geskiedenis is dat niemand daaruit leer nie, is waarskynlik hier ter sprake. Hierdie ontleding bevestig die gevolgtrekking soos gestel in "Suid-Afrika by 'n kantelpunt" (Duvenhage 2020:1-28), dat 'n "slegte-saak-scenario" voorhande is.

\section{BIBLIOGRAFIE}

ANC. 2017. ANC National Policy Conference: Strategy and tactics of the African National Congress. Discussion document,2017. https://www.sahistory.org.za/archive/2017-ANC-national-policyconference-strategy-and-tactics-of-the-african-national-congress-discussion-document (26 Januarie 2021 geraadpleeg).

Anon. 2019a. South Africa is one of the least safe countries in the world. 24 November. https:// businesstech.co.za/news/lifestyle/355519/south-africa-is-one-of- (15 Februarie 2020 geraadpleeg).

Tydskrif vir Geesteswetenskappe, Jaargang 61 No. 3: September 2021 doi.10.17159/2224-7912/2021/v61n3a5 
Anon. 2019b. Tax. Businesstech. 24 Desember. Businesstech.co.za (13 Februarie 2020 geraadpleeg).

Areff, A. 2015. Rich white men made Mandela turn against the revolution-Malema.https://www.news24. $\mathrm{com} /$ news24/soutafrica/news/rich-white-men-made-mandela turn against-against-the-RevolutionMalema. News 24. 26 November 2015 (7 Oktober 2020 geraadpleeg).

Baxter, J. 2020. Latest crime statistics for South Africa-increases in murder rate. https:/www.sapeople/ com/2020/07/31/latest-crime-statistcs-for-south-africa-increase-in-murder-rate (5 Oktober 2020 geraadpleeg).

Bloomberg. 2020. Advisory group puts a date to South Africa's collapse. Businesstech. https:// businesstech.co.za/news/business/432504/adviory-group-puts-a-date- to- South Africa's collapse. 10 September 2020 (20 Oktober 2020 geraadpleeg).

Brink, F. 2019. Ekonomiese groei uiters kommerwekkend. Nuusvrystelling/Onafhanklike ekonoom. 3 Desember, Bothaville.

Businesstech. 2021. Around 23000 tax residents leave South Africa each year and government to tighten the numbers. 5 March 2021. Bussinesstech.co.za.

Buys, F. 2020. "Rewolusie" van rykes. 22 Oktober 2020. MaroelaMedia.co.za.

Cameron, J. 2020. Flash briefing: SA heads for financial crisis; Denel. Land Bank needs funds, gold mines, COVID19. Biznews.com/entrepreneur/2020/10/11 financial crises (12 Oktober 2020 geraadpleeg).

Cameron, 2020A. Magnus Heystek: Horrific chart with nowhere for the JSE to hide. BIZNews. 27 December 2020. https://www.biznewes/wealth-advisors/2020/12/27magus-heystek-horrificchart-with-nowhere-to-hide-\#2020\#bestofbiznews (22 Maart 2021 geraadpleeg).

CEIC-Data. 2020. South African Debt: \% of GDP. Ouarterly CEIC-Data: September 2020. https://www. ceicdata.com/en/indicator/south-africa-debt-of nominal-gdp (8 Maart 2021 geraadpleeg).

Chipkin, I. \& Swilling, M. 2018. Shadow State: The politics of state capture. Johannnesburg: Wits University. $176 \mathrm{pp}$.

Complex system. 2019. Wikipedia. htts://en.wikipedia.org/wiki/complex-system (13 Februarie 2020 geraadpleeg).

Corruption Watch. 2020. South Africa's COVID-19 has exposed greed and spurred long needed action against corruption. Corruption Watch, 4 September 2020 (8 Maart 2021 geraadpleeg).

Cronjé, F. 2017. A traveller's guide to South Africa in 2030. Kaapstad: Tafelberg.

Cropley, E. 2018. Winnie Mandela, tarnished "Mother" of post-apartheid South Africa. World News. 2 April;1https://www.reuters.com/article/us-africa-winnie-mandela-idUSKCN11H91A6.

De Lange, R. 2020. Ekonomie kan met 7,3\% krimp. Sake Rapport, 26 Junie, p. 11.

De Vos, P. 2020. Court ruling on COVID-19 relief criteria affirms that the pandemic is not the "great equalizer". 23 June 2020.https://www.daily maverick.co.za./opinionista/2020-06-23-court-rulingon-COVID-19-relief-criteria-affirms-that-pandemic-is-not-the-great-equaliser (6 Maart 2021 geraadpleeg).

De Wet, P. 2016. SA Justice System is battling. https://mg.co.za/article/2016-9-16-00-SA's Justice system is battling (4/03/2021 geraadpleeg).

Duane, EC. 2017. Corruption and state capture under two regimes in Guyana (PDF). Research Gate. University of the West Indies (23 Mei 2017 geraadpleeg).

Dugard, J. 2001. From low intensity war to Mafia-war: Taxi violence in SA (1987-2000). Violence and transition series.vol.4 May 2001.

Duvenhage, A. 1998. Die krisis van die nasiestaat. Acta Academica, 31(3):1-35.

Duvenhage, A. 2003. Politieke verval as 'n patroon van politieke verandering: 'n Teoreties verkennende perspektief. Joernaal vir Eietydse Geskiedenis, 28(3):44-71.

Duvenhage, A. 2005. Politieke transformasie - 'n konseptuele oriëntering en Suid-Afrikaanse toepassing. Acta Academica, 37(3):1-40.

Duvenhage, A. 2005A. The dynamism of political transformation in South Africa - a general assessment. Communitas, vol.10:2005:1-19.

Duvenhage, A. 2007A. Politieke transformasie as 'n ideologiese raamwerk: 'n beleidsdinamiese analise en perspektief. Koers, 72(3):19-41).

Duvenhage, A. 2007. Die Suid-Afrikaanse politieke omgewing: 'n Strategiese ontleding en scenarioanalise. NWU (Potchefstroom): Professorale intreerede. 
Duvenhage, A.2016. Die Suid-Afrikaanse politieke omgewing: enkele strategiese perspektiewe. Tydskrif vir Geesteswetenskappe, 56(4-1):905-927.

Duvenhage, A. 2020. Suid-Afrika by 'n kantelpunt-'n slegte-saak-scenario? Litnet-Akademies. https:// www.litnet.co.za. Suid-afrika-by-'n-kantelpunt-'n-slegte-saak-scenario. 14 September 2020 (14 September 2020 ontsluit).

Duvenhage, A. 2020A. Suid-Afrika in 'n smeltkroes van verandering: eietydse en toekomsperspektiewe. Tydskrif vir Christelike Wetenskap, 2020 (vierde kwartaal):137-162.

Eisenberg, G. 2019. Is it time for a blanket amnesty for illegal foreigners living in SA? Daily Maverick: 28 August 2019.

Eunomix. 2020. South Africa heading towards a failed state.www.bloombergquint.com.politics.southafrica-heading-towards-becoming-a-failed-state. (10 Oktober 2020 geraadpleeg).

Geldenhuys, D. 1999. Staatsverval. Politeia, 18(2):37-56.

Gericke, M. 2020. R5,66 miljard kort vir waterkrisis. Volksblad. 16 September 2020: p. 4.

Gladwell, M. 2000. The tipping point: How little things can make a big difference. New York: Little Brown.

Global Peace Index. 2018. South Africa is one of the least safe countries in the world. htts://businesstech. co.za/news/lifestyle/355519/ South Africa is (16 Februarie 2020 geraadpleeg).

Gous, N. 2018. SA most unequal country in the world: Poverty shows apartheid's enduring legacy. 4 April. https://www.timelive.co.za/news/south-africa/2018-04-4 (20 Februarie 2020 geraadpleeg).

Gous, N.2019. Service delivery protests are on the rise this year, warns experts. 11 Junie. https://www. timeslive.co.za/news/south-africa/2019-06-11-service-delivery (20 Februarie 2020 geraadpleeg).

Granovetter, M. 1978. Threshold models of collective behavior. American Journal of Sociology, 84(6):1420-43.

Grodzinz, M. 1957. Metropolitan segregations. Scientific American, 197:33-47.

Grootes, S. 2020. After meeting KZN-veterans, Ace Magashule responds to Fikile Mbalula. Daily Maverick. https;//www.dailymaverick.co.za/article/2020-10-13-after-meeting-kzn-veterans-acemagashule-responds. (13 Oktober 2020 geraadpleeg).

Gumede, W. 2021.We are going down, the Mexican way. Sunday Times. 21 February 2021:24.

Gumede, W. 2021A, Mirror, mirror on the wall, who is the real leader of us all? Sunday Times Opinion \& Analysis. 17 March 2021.

Heleta, S. 2018. How many immigrants live in South Africa. https:afrcasacountry.com/2018/10/howmanymigrants-live-in Southafrica (16 Februarie 2020 geraadpleeg).

Heystek, M. 2019. RSA titanic is in groot k\#k - don't let those patriotic swimsuits fool you. Biznews. com. 24 Desember. Businesstech.co.za+ (17 Februarie 2020 geraadpleeg).

Heywood, A. 2002. Politics (second edition). New York: Palgrave Foundations.

Human, P. 1998. Yenza: a blueprint for transformation. Oxford: Oxford University Press.

Huntington, SP. 1965. Political development and political decay. World Politics, 17(2):386-430.

Huntington, SP. 1968. Political order in changing societies. London: Yale University Press.

Johnson, RW. 2019. Our coming train crash. Politicsweb. 1 Augustus (20 Februarie 2020 geraadpleeg).

Johnson, RW. 2020a. Ineenstorting wag op ANC. Rapport Weekliks. 27 September 2020:7.

Johnson, RW. 2021. Ramaphosa's losing strategy. 6 March 2021. Politicsweb (8 Maart 2021 geraadpleeg).

Joubert, P. 2014. 100 years of income tax in SA-SRI. Politicsweb-news and analysis: Solidarity Research Institute (18 Februarie 2020 geraadpleeg).

Kekana, M. 2019. Financial state of municipalities has worsened - Auditor General. Mail and Guardian. 26 Junie. https://mg.co.za/article/2019-06-26-financial-state-of-municipalities (19 Februarie 2020 geraadpleeg).

Khumalo, J. 2020. Moboweni faces wage battle. City Press: 21 Junie:1-2.

Kinnaird, BA. The Criminal Justice System is broken and can't be fixed. https://www.psycology.com/ za/blog/the-hero-in-you/2001812/the-criminal-justice-system-is-broken-and-can't-be-fixed (4 Maart 2021 geraadpleeg).

Krige, N. 2019. Bheki Cele has the private security industry in his sights. https://www.the southafrican. com/news/bheki-cele-has-the-private-security-interest-in-his-sight: 28 March 2020 (20 Februarie 2021 geraadpleeg). 
Magashule, A. 2018. National Conference Report and Resolutions. https:www.polity.org.za/article/54thnational-conference-report-and-resolutions-2018-03-26 (4 Maart 2021 geraadpleeg).

Malan, K. 2012. Politocracy - an assessment of the coercive logic of the territorial state and ideas around a response to it. Pretoria: Pretoria University Law Press,

Malan, K. 2014. Taalverval met besondere verwysing na die ideologieë en praktyke van verstaatliking. Tydskrif vir Geesteswetenskappe, 54(3):462-480.

Malan, K. 2019. There is no Supreme constitution - a Crtique of Statist-individualist Constitutionalism. Pretoria: African Sun Press.

Merten, M. 2019. State Capture wipes out third of SA's R4,9-trillion GDP- never mind lost trust, confidence, opportunity. 1 Maart 2019. https://dailymaverick.co.za/article/2019-03-01-state-capturewipes-out-third-of SA,s-R4,9-trillion-GDP-never-mind-lost-trust-confidence-opportunity (18 Maart 2021 geraadpleeg).

Migdal, JS. 1988. Strong societies and weak states: State-society relations and state capabilities in the third world. Princeton: Princeton University Press.

Moboweni, TT. 2020. Supplementary budget speech. National Treasury: Republic of South Africa.

Mokgoro, J. 2018. North West Provincial Overview on section 139 (ii) intervention. PEC-discussion. 22 August 2018:1-3.

Myburg, P-L. 2019. Gangster state - Unravelling Ace Magashule's web of capture. Cape Town: Penguin.

Odendaal, N. 2017. South Africa on path of deindustrialization. Creamer media: Engineering news. 5 Oktober. https://www.enineering news.co.za/article/south-africa-continues (16 Februarie 2020 geraadpleeg).

Pauw, J. 2017. The President's Keeper - those keeping Zuma in power and out of prison. Cape Town: Tafelberg.

Parsons, R. 2020. Note of comment - immediate release. Potchefstroom. NWU: Business School.

Parsons, T. 1951. The social system. London: Routledge.

Popper, K. 1971. The Open Society and its Enemies. Princeton: Princeton University Press.

Private security in South Africa. 2019. Wikipedia. https://en.wikipedia.org/wiki/private security (19 Februarie 2020 geraadpleeg).

Romano, S. 1947. The legal order. Abingdon: Routledge.

Schelling, T. 1971. Dynamic models of segregation. Berkeley: Department of Statistics.

Schüssler, M. 2020. Staat op snelweg na mislukking. Netwerk 24. 21 September 2020:7.

Seliger, M. 1976. Ideology and politics. London: George Allen \& Unwin.

Service delivery protests. 2019. Wikipedia. https://en.wikipedia.org/wiki/2019-service delivery-protests (20 Februarie 2020 geraadpleeg).

Snyman, CR. 2008. Criminal Law (fith edition). Durban: Lexis Nexis.

Soobramoney, V. 2017. Capital outflow: R350 million has left South Africa. https://www.iol.co.za/ business-report/capital-outflow-r350billion (18 Februarie 2020 geraadpleeg).

South African Bussiness Confidence. 2020. South African business confidence -1975-2020-data/20212022 forecast. https://trading economics.com/south african business confidence (10 Oktober 2020 geraadpleeg).

Steenkamp, L. 2019. South African taxpayers will bear the brunt of National Health Insurance. 29 Augustus. The Conversation. htts://theconversation.com/south-african-taxpayers-will-bear(17 Februarie 2020 geraadpleeg).

Stern, K. 1984. Das Staatsrecht der Bundesrepublik Deutschland. München. ISBN 3-406-09372-8.

Steward, SJ. 1990. Does God play dice? The mathematics of chaos. Blackwell Publishers.

Strachan, G. 2017. South Africa continues on path of deindustrialization. Engineering news: Creamer Media (Africa Energy Indaba).

The African Project. 2021. SA: Zuma spy allegations could splash Ramaphosa, too. https://www.the african report.com/62340/ south-africa-zuma-spy-allegations-could-splash-ramaphosa-too (3 Maart 2021 geraadpleeg).

Toffler, A. 1990. Power Shift - knowledge, wealth and violence at the edge of the 21st century. London: Bantam Books.

Tonnies, F. 1905. The present problems of social structure. The American Journal of Sociology, 10(5):569688. 
Turton, A. 2019. Going backwards - the deindustralization of the South African economy: Facebook: Facebook-blad (19 Februarie 2020 geraadpleeg).

Van der Groenendaal, H. 2017. South Africa has been captured by deindustrialization. https:// mybroadband.co.za/news/business/220990.south-africa-has-been (19 Februarie 2020 geraadpleeg).

Versluis, J-M \& De Lange, J. 2019. How law enforcement in SA has all but collapsed. News24, 21 Oktober. 21/102019. https://city-press. News 24.com/News/rising-crime-low-prosecution (20 Februarie 2020 geraadpleeg).

Weber, M. 1964. The theory of social and economic organization. New York: Free Press.

Wicks, J \& Ash, P.2020. It's going to have a devastating effect: Jobs ax hang over half of SA workforce. Sunday Times, 3 May: p. 23.

Wikipedia. 2020. Social engineering (political science). https://en.wikipedi.org/wiki/Social_engineering (political science) (02 Desember 2020 geraadpleeg).

Winning, A. 2020. South Africa's unemployment rate reaches record high above 30\%. https://www. reuters.com/article/safrica-economy-unemployment-id-USKBN 27S25D (5 Maart 2021 geraadpleeg).

Zartman, IW (ed.). 1995. Collapsed states: The disintegration and restoration of legitimate authority. Boulder, CO: Reiner. 